\title{
BALANCE SCORECARD DALAM ANALISIS KINERJA KOPERASI (Studi Kasus pada Koperasi Unit Desa (KUD) Bayongbong Kabupaten Garut, Jawa Barat)
}

\author{
BALANCE SCORECARD IN COOPERATIVE PERFORMANCE ANALYSIS \\ (Case Study on Village Unit Cooperative (KUD) Bayongbong Garut Regency, West Java) \\ Gijanto Purbo Suseno ${ }^{1}$, Nataliningsih ${ }^{2}$ and Nuni Wahyuni ${ }^{3}$ \\ ${ }^{1,3}$ The Institute for Research and Community Service, Ikopin, Sumedang (40600), Indonesia \\ ${ }^{2}$ University of Winayamukti, Bandung (40123), Indonesia
}

Email: givantops25@gmail.com

\begin{abstract}
Village Unit Cooperative (KUD) Bayongbong Garut Regency, Wes Java, is a livestock cooperative whose business activities are multi purpose. The purpose of cooperatives is to improve the welfare of members in particular and society in general, in accordance with the interests and needs of its members. The purpose of this study is to measure the performance of cooperatives by using Balanced Scorecard and efforts to be done so that cooperatives can improve its performance. Balanced Scorecard is a rapid measurement and eontrol management system, precise and comprehensive, consisting of four perspectives: financial, customer internal business processes and learning and growth. The results showed that the non-financial perspective of internal business consisting of livestock food business, cooperation business with State Electricity Company (PLN), Convenience Store, have a better perspective with score score 372, compared with $\backslash$ other perspective that is customer perspective with value 832 and growth learning perspective with score 492. Suggestions that can be submitted are independent KUD Bayongbong must be able to improve service for customers and employee satisfaction, provide adequate information system and provide learning or training for its employees.
\end{abstract}

Keywords: Balance Scorecard, cooperative performance, four perspectives, service improvement

Koperasi Unit Desa (KUD) Bayongbong Kabupaten Garut, adalah koperasi peternak yang kegiatan usahanya bersifat multi guna. Tujuan koperasi adalah untuk meningkatkan kesejahteraan anggota pada khususnya dan masyarakat pada umumnya, sesuai dengan kepentingan dan kebutuhan anggotanya. Tujuan dari penelitian ini adalah untuk mengukur kinerja keperasi dengan menggunakan Balanced Scorecard dan upaya yang dilakukan agar koperasi dâpat meningkatkan kinerjanya. Balanced Scorecard adalah sistem manajemen pengukuran dan pengendalian yang cepat, tepat dan komprehensif, terdiri dari empat perspektif: keuangan, pelanggan, proses bisnis internal dan pembelajaran dan pertumbuhan. Hasil penelitian menunjukkan bahwa perspektif non finansial bisnis internal yang terdivi dari usaha makanan ternak, usaha kerjasama dengan Perusahaan Listrik Negara (PLN), Convenience Store, memiliki perspektif yang lebih baik dengan skor skor 372, dibandingkan dengan perspektif lain yaiı perspektif pelanggan dengan nilai 832 dan perspektif pembelajaran pertumbuhan dengan skor 492. Saran yang dapat diajukan adalah KUD Bayongbong yang independen harus dapat meningkatkan pelayanan bagi pelanggan dan kepuasan kerja, memberikan sistem informasi yang memadai dan memberikan pembelajaran atau pelatihan bagi karyawannya. 
Kata kunci: Balance Scorcard, kinerja koperasi, empat perspektif, peningkatan pelayanan

\section{INTRODUCTION}

Cooperative is a business entity that concerns the common interests not only individuals, based on open and democratic principles of kinship in the direction of a strong economy and a developed, self-sufficient and equitable society. This is a hard task for the cooperative so that the cooperative must be tough, positive thinking and deeply rooted in society and still exist in growth and development in global competition. To know the competition ability of a cooperative, the assessment of the performance of the cooperative is absolutely done in order to determine the right step for the next development of the cooperative.

Performance appraisal is done regularly and directed to improve performance in the future. The forms of assessment include emphasis on product quality, cost and price quality, service quality, quality of delivery, which can be done on time, quality of aesthetics and other qualities evolving to provide satisfaction and continuously to customers to create loyal customers (Hansen and Mowen, 1999)

Bayongbong Independent Vilage Unit Cooperative (KUD Mandiri Bayongbong) district of Garut, West Jaya, was established since 1973. Until now the business unit managed is dairy cattle business unit, animal feed unit, Electricity service ünit, Convenience Store unit, Savings and Loan unit, with total Surplus (SHU) in 2014 IDR 588,215,616,53, with Return On Assets (ROA) equal to 3,22\%. The greater the cooperative's ability to use assets to generate SHU, the more efficient the asset is used. Referring to the criteria of cooperative health level based on the Regulation of the State Minister of Cooperatives and SME's RI, Number 06 / Per / M.KUKM / 2006, from the result of small ROA (3.22\%), then the classification of cooperatives enter the criteria of less healthy cooperatives. This means that the cooperative has not been able to maximize the use of its assets in producing SHU.

Based on the development of the number of members from 1970 people in 2011 to 2,043 people in 2014, indicating a slight increase. However, when viewed from the number of incoming members (35 people in 2011 and 33 in 2014) and outgoing (114 people in 2011 and 89 in 2014), there are still more number of outgoing members. This is thought to be due to lack of cooperatives to maximize the fulfillment of the needs of its members. the needs of the members or the products presented are less suitable to the needs of the members, thus making less attractive to new members.. Based on the number of Surplus, ROA and increase in the number of members indicates that not only financial consideration but non-finaricial need to be considered for the deyelopment of a cooperative. One method that can be used to balance business and executive attention to financial and nonfinancial performance is the Balanced Scorecard method. BSC is one of the tools than can be used to measure the business performance of one business entity, covering four perspectives, namely financial, customer, internal business and growth and learning perspectives. Therefore, through performance measurement using the BSC method, it is expected to provide comprehensive information on cooperative performance, so that management can perform appropriate actions so that the cooperative can run well.

The purpose of this research is to apply Balance Scorecard method to analyze the performance of Village Unit Cooperative (KUD) Bayongbong, Garut, West Java, for short and long term performance in 4 perspectives. Which means allowing non-financial actions "key indicators" to control the financial size of "lag indicators" and predict future financial performance (Kaplan and Norton within Guidara and Khoufi, 2014)

\section{RESEARCH METHODS}

The research approach is qualitative with descriptive method, to all aspects, related to 4 data perspectives in Balance scorecard, and to know the efforts that must be done by KUD Mandiri Bayongbong in achieving optimal performance. The sample size of 35 members was taken with simple random sampling technique. Sampling of employees was taken purposively as many as 15 people.

\section{LITERATURE REVIEW}

Balanced Scorecard (BSC) is one of the analytical tools that can be used to measure the 
performance of an organization, in order to achieve business goals, through the strategy set. This analysis was first developed by Robert Kaplan and David Norton at Harvard Business School in early 1996 . The main problem that Kaplan and Norton identified at the time was, the number of organizations that tended to assess their business performance by focusing on financial measures, but tended to ignore other measures, even though they are already working well at first. In addition, it significantly shows that at this time the business tempo requires a wider and comprehensive measure, to measure a business that ultimately becomes successful in the next business pace. (Binden, Mziu, \& Suhaimi, 2014)

The BSC approach, widely recommended its use. Its development is done continuously. Since the BSC approach was introduced, many researchers have widely investigated the advantages and disadvantages of this analytical tool, which are linked to factors such as communicators, integration and measurement indicators. They find out, 1) the need to translate strategy and channel organization effectively, 2) the importance of this approach and integrate it efficiently in the measurement of operational procedures. 3 ) the design, use and measurement of the indicators. (Kopecka, 2015).

There are four perspectives items in the BSC approach, namely finance, customer relations, internal business process and, learning and growth. Financial perspective plays a dual role of defining the financial performance of an organization with the implementation and execution of the company's strategic plans, as well as evaluating the organization's profitability using tools such as Return on Investment (ROI) and Economic Value Added (EVA). Customer perspective is an indicator that helps the organization evaluates customer satisfaction with its products. Ensuring strong customer loyalty, in addition to attracting new customers is something that is very necessary..(Zin, Sulaiman, Ramli, \& Nawawi, 2013).

In Indonesia, cooperatives have a very important role in the national economy. Cooperative aims to improve the welfare of members in particular and society in general, as well as an integral part of the order of the national economy is democratic and fair. The cooperative sector serves as a community support for the small and medium enterprise sector. Seeing the reality like this, it is necessary to make improvements in the cooperative management system.

Compared to the commercial private sector, the growth of co-operatives in the last twenty years, not too exciting. The most noticeable is a cooperative engaged in the agricultural industry, with members of the farmers. With member products that are easily damaged, these cooperatives require credit facilities, both to support the sustainability of their members' eifforts, as well as to support investment in order to increase the added value of its member products. However, creditors, including banking institutions, are usually not so eager to do business with agricultural cooperatives. This is possible given the risk of perishable agricultural products.

In Spain, the cooperative sector represents one of the most important institutions in the countryside. Efforts to improve rural road infrastructure are carried out in the framework of developing rural economic areas. In addition to maintaining the sustainability of the per capita income stability of the rural population, despite its small contribution to the economy, agrarian cooperatives are stimulated to enter the international market. For many years the cooperativism and the commercialization has turned into an economic reality consolidated for the agrarian sector (Martin, Molina and Ruiz: 2009 in Martín López and Ruiz Guerra, 2011). In order to encourage the cooperative sector to enter the international market, it is necessary to develop an appropriate strategy for the cooperative, with minimal risk impact. To formulate the strategy, one approach that can be implemented is to use BSC analysis.

Previous BSC analysis results show an indirect relationship between the intensity of market competition and business performance. However, for the partial hypothesis, results indicate that the intensity of market competition isn't a determinant of the use of the financial perspective of the BSC. In fact, financial measures are used regardless the market context. In this paper, we attempted to study 
balanced scorecard and performance in a competitive environment. Our treatment has been necessarily brief and certainly no exhaustive. For instance, we studied the theoretical Kaplan and Norton model; there are other performance measure systems. Then, we studied the agro-food Tunisian firms and ignored others sectors. Future research can extend this study by investigating new strategic performance measure system, other variables (technologies, culture.) and others economic sector (Guidara \& Khoufi, 2013)

Balance Scorecard applied in dairy cooperative shows that for long term performance need analysis of marketing management of milk, making concentrate, need coaching milk breeder through counseling for member of cooperative so that cooperative is healthier (Purwono, Sugyaningsih, \& Roseriza, 2013). Through this analysis, the less healthy cooperative milk can be improyed its performance to be healthy with the improvement of financial and non financial.

With a balanced scorecard it is possible to translate organizational vision and strategy into detailed objectives with performance measurements divided into four important perspectives so that the organization's leadership can consider all the important operational measures simultaneously. Balanced scorecard is a mechanism to translate strategies and tactics simultaneously so that policies and activities can be measured from plan, implementation and to result. Thus, in preparing the balanced scorecard should be preceded by the deepening of the vision and mission of an organization and short-term performance analysis to obtain long-term performance analysis in terms of financial and non-financial aspects (Sinaga, 2015).

In general, to assess the performance of an organization, people focus more on financial performance. Similarly, BSC analysis, in assessing the performance of the organization, also gives emphasis on financial goals. However, the advantage of this analysis is to try to balance the assessment of organizational performance, not only in the financial perspective, but also on the other three perspectives. These four perspectives are also contained in the Proceedings of the Twelfth Australasian Conference on Information Systems, namely; (1) financial perspective, (2) customer perspective, (3) internal business process perspective and (4) learning and growth perspective.(Sedera, Gable, \& Rosemann, 2001)

Cooperatives as one of the organizations that are not only concerned with the acquisition of profits alone, have important characteristics that are visible from the functions and roles mandated by Law no. 25/1992, anong which is to build and develop the potential and economic capacity of member's in particular and society in general to improve their economic and social welfare (Cooperative Act). However, in reality the cooperative has not been able to conduct a good performance appraisal. In a balanced score-card model for cooperatives, this perspective is called a membership perspective. This membership perspective may be more appropriate instead of replacing the customer's perspective, but is an extension of the customer's perspective in its usual form. Thus, the measures used should also accommodate the member's unique position, ie the member as the owner and simultaneously as a customer. Empirical conditions above it feels cooperative requires a performance assessment in accordance with the characteristics of cooperative business entities. This context is the significance of the study on the implementation of the balanced scorecard as a benchmark of performance appraisal on business entities in the form of cooperatives. (Ikhsan \& Ikhsan, 2012).

The results of previous research in KUD Setia showed that the average value of KUD Setia performance measurement based on the Regulation of State Minister of Cooperatives and Small and Medium Enterprises of the Republic of Indonesia (Ministerial regulation No. 06 / M.KUKM / V / 2006) on organizational aspect, management aspect, Aspects of productivity and benefits and impact aspects obtained the average value of KUD Setia's performance of 67.08 with fairly good criteria. Based on the measurement of satisfaction level of KUD Setia members towards the administration of cooperatives, work culture of the board, cooperative finance, Rice Miling Unit (RMU) business, savings and borrowing business and electricity and water bill collectio. In order to improve future performance, KUD Setia is expected to conduct 
cooperative education activities at managers and members of cooperatives. In addition, it is necessary to draw up a Work Plan (RK) and cooperative budget plan (RAPB) of the Cooperative by involving members, so that it fits the members' needs for the future performance analysis. The financial ratios used are the ratio of liquidity, solvency ratio and the ratio of own capital. But to achieve long-term performance success, must be supported by the success of non-financial performance that includes perspektif customers (members of the cooperative), internal business process perapective and learning and frowth perspective. To achieve the success of cooperatives required a performance measurement tool that not only measures the development of KUD Setia (Karni, Pertanian \& Andalas, 2011).

The current performance appraisal used by KUD Bayongbong is by using financial

financial performance but also can measure non-financial performance in order to balance the financial and non financial performance that can assist management in evaluating the performance comprehensively. In detail, the indicators that used to measure the business performance of the cooperative in four dimensions of BSC can be seen in the following of the variable operationalization table.

Table 1. Variable Operazionalization

\begin{tabular}{|c|c|c|c|c|}
\hline No & Variable & Sub Variable & Dimension & Indicator \\
\hline \multirow[t]{4}{*}{1} & \multirow{4}{*}{$\begin{array}{l}\text { Financia } \\
1 \text { perfor- } \\
\text { mance }\end{array}$} & \multirow[t]{4}{*}{$\begin{array}{l}\text { Financial } \\
\text { perspective }\end{array}$} & liquidity ratio & $\begin{array}{l}\text { 1.Current asset } \\
\text { 2.Current liabilities }\end{array}$ \\
\hline & & & Solvency ratio & $\begin{array}{l}\text { 1) Total debt } \\
\text { 2. Total assets }\end{array}$ \\
\hline & & & Activity ratio & $\begin{array}{l}\text { 1.Sales } \\
\text { 2. total assets }\end{array}$ \\
\hline & & & Ratio of own capital & 1.Surplus \\
\hline \multirow[t]{9}{*}{2} & \multirow{9}{*}{$\begin{array}{l}\text { Non } \\
\text { finanial } \\
\text { perfor- } \\
\text { mance }\end{array}$} & \multirow[t]{3}{*}{$\begin{array}{l}\text { Customer } \\
\text { (members) } \\
\text { perspective }\end{array}$} & Customer retention & $\begin{array}{l}\text { 1.Products offered } \\
\text { 2.Adequate facilities } \\
\text { 3.The timeliness of service }\end{array}$ \\
\hline & & & Customer acquisition & $\begin{array}{l}\text { 1.Customer trust } \\
\text { 1.Customer's satisfaction with the product } \\
\text { 2.Kepuasan service } \\
\text { 3.Customer satisfaction level }\end{array}$ \\
\hline & & & Customer satisfaction & $\begin{array}{l}\text { 1.Provision of new products } \\
\text { 2.Information of information technology } \\
\text { 3.Compatibility of product price level }\end{array}$ \\
\hline & & \multirow{3}{*}{$\begin{array}{l}\text { Internal business } \\
\text { process perspective }\end{array}$} & Innovation process & 1. Provision of new products \\
\hline & & & Operation & $\begin{array}{l}\text { 1. Working facilities } \\
\text { 2. Compatibility of information technology } \\
\text { 3. Suitability of the product price levels }\end{array}$ \\
\hline & & & After sales service & $\begin{array}{l}\text { 1.Complaints received } \\
\text { 2. Follow up on customer complaints } \\
\text { 3. Follow-up of returned products }\end{array}$ \\
\hline & & \multirow[t]{3}{*}{$\begin{array}{l}\text { Learning and } \\
\text { growth perspec-tive }\end{array}$} & Employee capability & $\begin{array}{l}\text { 1. Working hours } \\
\text { 2. Award given } \\
\text { 3.Compensation provided } \\
\text { 4.The willingness to get the worker out }\end{array}$ \\
\hline & & & $\begin{array}{l}\text { Information system } \\
\text { capability }\end{array}$ & $\begin{array}{l}\text { 1. Availability of information } \\
\text { 2. Socialization / delivery of information }\end{array}$ \\
\hline & & & $\begin{array}{l}\text { Motivation of } \\
\text { empowerment and } \\
\text { alignment }\end{array}$ & $\begin{array}{l}\text { 1.Education and training to employees } \\
\text { 2. Implementation of suggestions from employees } \\
\text { 3.The results of the suggestion shown } \\
\text { 4.Compatibility of organizational and employee goals }\end{array}$ \\
\hline
\end{tabular}




\section{RESULTS AND DISCUSSION}

\subsection{Financial perspective}

The development of KUD Mandiri Bayongbong's overall surplus from 2011-2014 can be said to increase as shown in the table 2 . Table 2 shows a significant increase in financial development in all business units, except cooperation with PT. PLN in electricity

bill payment. This happens because the electricity bill payment line has many changes and can be done in various ways, among others, through banks, internet cafes, early payment (prepaid electricity), through the post office and so on, so that customers seek easy

payment place near his home.

Table 2. Financial analysis of each business unit of the cooperative

\begin{tabular}{|l|l|l|l|l|}
\hline No & Type of business & $\begin{array}{l}\text { Surplus } \\
\text { Year 2011 (IDR) }\end{array}$ & $\begin{array}{l}\text { Surplus } \\
\text { Year 2014 (IDR) }\end{array}$ & $\begin{array}{l}\text { Change } \\
(\%)\end{array}$ \\
\hline 1 & Dairy cattle business & $313.701 .483,62$ & $415.004 .757,00$ & 13,97 \\
\hline 2 & Fodder business & $15.552 .100,00$ & $335.161 .223,00$ & 612,15 \\
\hline 3 & $\begin{array}{l}\text { Business cooperation with National } \\
\text { Electricity Company }\end{array}$ & $77.356 .016,00$ & $52.682 .849,00$ & $-22,58$ \\
\hline 4 & Savings and Loans Business & $78.344 .370,00$ & $246.946 .951,00$ \\
\hline 5 & Special credit for trader business & $2.636 .000,00$ & $2.694 .000,00$ \\
\hline 6 & Convenience store business & $15.477 .900,00$ & $32.399500,00$ \\
\hline
\end{tabular}

Financial condition analysis from KUD Mandiri Bayongbong viewed from various financial analysis can be seen in table below.

Tabel 3. Analysis of the financial condition of the cooperative in terms of various financial analysis

\begin{tabular}{|c|c|c|c|c|c|c|c|c|}
\hline \multirow{2}{*}{$\begin{array}{l}\text { No } \\
1\end{array}$} & \multicolumn{2}{|c|}{ Type of analysis } & \multicolumn{3}{|c|}{$\begin{array}{l}\text { Ministerial regulation No.06 / } \\
\text { M.KUKM / V / 2006 }\end{array}$} & Year & $\begin{array}{l}\text { Performance } \\
\text { Indicators }\end{array}$ & Criteria \\
\hline & \multirow[t]{5}{*}{$\begin{array}{l}\text { Liquidity } \\
\text { ratio }\end{array}$} & \multirow[t]{2}{*}{$\begin{array}{l}\text { Current } \\
\text { assets }\end{array}$} & $\begin{array}{l} \\
\\
\end{array}$ & Ratio (\%) & $\begin{array}{l}\text { Criteria } \\
\text { Very good }\end{array}$ & 2012 & 189.22 & Good \\
\hline & & & 2 & $\begin{array}{c}175-<175 \text { o } \\
>250-275\end{array}$ & Good & \multirow[t]{2}{*}{2013} & \multirow[t]{2}{*}{158.51} & \multirow[t]{2}{*}{ Good enough } \\
\hline & & \multirow{3}{*}{$\begin{array}{l}\text { Cuprent } \\
\text { libilities }\end{array}$} & 3 & $\begin{array}{l}150-<17.5 \text { or } \\
>275-309\end{array}$ & Good enough & & & \\
\hline & & & & $\begin{array}{l}125<250 \text { or } \\
300-375\end{array}$ & Not good & \multirow[t]{2}{*}{2014} & \multirow[t]{2}{*}{175.03} & \multirow[t]{2}{*}{ Good } \\
\hline & & & 5 & $<125$ or $>325$ & bad & & & \\
\hline \multirow[t]{5}{*}{2} & \multirow{5}{*}{$\begin{array}{l}\text { Solvability } \\
\text { Ratio }\end{array}$} & \multirow{5}{*}{ Total debt } & No & $\begin{array}{ll}\text { Ratio (\%) } \\
\end{array}$ & $\begin{array}{l}\text { Criteria } \\
\end{array}$ & 2012 & 48.35 & \multirow[t]{2}{*}{ Good } \\
\hline & & & 1 & $\leq 40$ & Very good & & & \\
\hline & & & 2 & $>40-50$ & Good & 2013 & $\$ 1.63$ & Good enough \\
\hline & & & $\frac{3}{4}$ & $\begin{array}{l}>50-60 \\
>60-80\end{array}$ & $\begin{array}{l}\text { Good enough } \\
\text { Not good }\end{array}$ & 2014 & 49.98 & Good \\
\hline & & & 5 & $>80$ & bad & & & \\
\hline \multirow[t]{5}{*}{3} & \multirow{5}{*}{$\begin{array}{l}\text { Rentability } \\
\text { Ratio }\end{array}$} & \multirow{3}{*}{ Surplus } & No & Ratio (\%) & Criteria & 2012 & \multirow[t]{2}{*}{6.5} & \multirow[t]{2}{*}{ Not good } \\
\hline & & & 1 & $\geq 21$ & Very good & & & \\
\hline & & & 2 & $15-<21$ & Good & 2013 & 7.39 & Not good \\
\hline & & \multirow[t]{2}{*}{ Own capital } & $\frac{3}{4}$ & $\frac{9-<9}{3-<9}$ & $\begin{array}{l}\text { Good enough } \\
\text { Not good }\end{array}$ & 2014 & \multirow[t]{2}{*}{4.37} & \multirow[t]{2}{*}{ Not good } \\
\hline & & & 5 & $\frac{3-y}{<1}$ & bad & & & \\
\hline \multirow[t]{5}{*}{4} & \multirow{5}{*}{$\begin{array}{l}\text { Activity } \\
\text { Ratio }\end{array}$} & \multirow[t]{3}{*}{ Sales } & No & Ratio (\%) & Criteria & 2012 & \multirow[t]{2}{*}{1.87} & Not good \\
\hline & & & 1 & $\geq 10$ & Very good & & & \\
\hline & & & 2 & $7-<10$ & Good & 2013 & 206 & Not good \\
\hline & & Total assets & 3 & $3-<7$ & Good enough & & & \\
\hline & & & $\frac{4}{5}$ & $\frac{1-<3}{<1}$ & $\frac{\text { Not good }}{\text { bad }}$ & 2014 & 2.23 & Not good \\
\hline
\end{tabular}


From the table above shows that from the side of liquidity and solvability shows the cooperative able to pay its debts. But it can be seen that the cooperative is financed by almost half of its debt. If the company will increase its debt, then need to add equity. For rentability ratio, indicating that cooperative is still not effective in obtaining SHU. Similarly, small

activity ratios, indicating that cooperatives are still not effective in utilizing existing.

\subsection{Customer perspective}

Customers in this case include members and non members who are important elements in the cooperative, so that customer service needs to be considered which will determine the success of the cooperative. The customer perspective is viewed from 3 sides: customer retention, customer acquisition and customer satisfaction.

1. Customer retention

The questionnaire results of several variables that support in customer retention can be seen in the table below.

Table 4. Customer retention value

\begin{tabular}{|l|l|l|l|l|}
\hline No & Variables & $\begin{array}{l}\text { Good } \\
\text { enough (\%) }\end{array}$ & Good (\%) \\
\hline 1 & Products offered by cooperative & 64,71 & Avery good (\%) & Average \\
\hline 2 & $\begin{array}{l}\text { Adequate facilities for customer } \\
\text { service }\end{array}$ & 57,14 & Good enough \\
\hline 3 & Timeliness in service & 28,57
\end{tabular}

From result of analysis indicate that still need improvement in provision of facility and type of product offered by cooperative so that customer fulfilled his needs and feel satisfied to service given.

2. Customer acquisition

Is a dimension to build trust and image of customer to KUD Mandiri, indicator that is used is customer trust to product or service offered by cooperative. The result of analysis shows that the trust level of the customer shows that trust enough is $62.86 \%$ and believe it is $37.14 \%$ so the average value is good enough. From here still needed an increase in customer confidence so that it becomes a good average. High trust will increase the number of customers because the promotion of people is easier and more reliable.

\section{Customer satisfaction}

The level of customer satisfaction can be reviewed from several variables so that can be known aspects that increase satisfaction and add value customer satisfaction. The results of customer satisfaction analysis are presented in the table below.

Table 5. Level of customer satisfaction to the cooperative

\begin{tabular}{|l|l|l|l|l|l|}
\hline No & Variables observed & $\begin{array}{l}\text { Quite } \\
\text { satisfied }(\%)\end{array}$ & Satisfied (\%) & $\begin{array}{l}\text { Very satisfied } \\
(\%)\end{array}$ & Average \\
\hline 1 & Products produced & 68,57 & 31,43 & $\begin{array}{l}\text { Quite } \\
\text { satisfied }\end{array}$ \\
\hline 2 & Services provided & 37,14 & 54,29 & & Satisfied \\
\hline 3 & $\begin{array}{l}\text { Product services, facilities } \\
\text { and services }\end{array}$ & 57,14 & 34,29 & 8,57 & Satisfied \\
\hline
\end{tabular}

Based on the analysis of customer satisfaction levels show the variables of the product produced to get the criteria is quite satisfactory, therefore the strategy must be done is to increase the type of product so as to increase customer satisfaction.

\subsection{Internal business process perspective}

The internal business process perspective is to support the financial perspective and customer perspective, so that it can be identified the key processes that must be managed by the cooperative in terms of innovation, operation and after sales service dimensions. 
1. Dimensions of the innovation process It is a dimension to know the set of process. It is necessary first step in the form of really needed by customer which impact on the improvement of product quality offered by management in meeting the needs and welfare of its members, to make the innovation. The result of analysis shows that $13.33 \%$ shows less change (innovation), 33,33\% enough change and $53,33 \%$ there is change. This shows that

Table 6. Dimensions of operation in dairy cattle business

\begin{tabular}{|l|l|l|l|l|l|}
\hline No & Variables & $\begin{array}{l}\text { Quite } \\
\text { appropriate } \\
(\%)\end{array}$ & $\begin{array}{l}\text { Appropriate } \\
(\%)\end{array}$ & $\begin{array}{l}\text { Very } \\
\text { appropriate } \\
(\%)\end{array}$ & Average \\
\hline 1 & Equipment used in MCU & 13,33 & 66,67 & 13,33 & Good \\
\hline 2 & $\begin{array}{l}\text { Technology used by } \\
\text { employees }\end{array}$ & $\begin{array}{l}\text { Go,67 } \\
\text { ponformity of the product }\end{array}$ & 6,67 & 33,33 & 93,33 \\
\hline 3 & \begin{tabular}{l} 
price \\
\hline
\end{tabular}
\end{tabular}

From the above table shows the need for improvement strategies in technology used by employees to be more efficient, effective and profitable so as to improve employee performance in MCU the innovations undertaken by cooperatives to improve product quality is good. This is proven by the plans for convening the packaging of milk production by the cooperative.

\section{Dimensions of operation}

The dimension of operation related to dairy cattle business is MCU (Milk Cooling Unit), several variables observed from the dimension presented in table below.

Table 7. Dimensions of aiter-sales service to cooperative products

\begin{tabular}{|c|c|c|c|c|c|}
\hline No & Variables & $\begin{array}{l}\text { Just follew up } \\
(\%)\end{array}$ & Follow up $(\%)$ & $\begin{array}{l}\text { Very follow } \\
\text { up }\end{array}$ & Average \\
\hline 1 & Customer complaints & $60 \square$ & & & Good enough \\
\hline 2 & $\begin{array}{l}\text { Follow-up of cuistomer } \\
\text { complaints }\end{array}$ & 20 & 66,67 & 13,33 & Good \\
\hline 3 & $\begin{array}{l}\text { Follow-up of Product } \\
\text { returns }\end{array}$ & 6,67 & 93,33 & & Good \\
\hline
\end{tabular}

From the table indicates the need for improvements in handling customer complaints, the customer is the king, the less responsive complaints may result in the customer not returning to the cooperative, therefore need improvement in the handling of customer complaints, even if necessary a special section that handles complaints and complaints from customers.

\subsection{Leaarning and growth perspective} This perspective is the foundation of success for
3. Dimensions of after-sales service In this activity there are several observed variables concerning customer complaints, follow-up of customer complaints and followups or responses to product returns. The overall results can be seen in the table below. cooperative organizational environments, so it is important to be assessed to encourage cooperatives to become a learning organization that can continually improve its quality and capacity for the future. Dimensions used in this perspective include worker capability, information systems and motivation capabilities, empowerment and alignment. Overall analysis results are listed in the table below.

Table 8. Perspective on learning and growth in cooperative

\begin{tabular}{|c|c|c|c|c|c|}
\hline $\mathrm{N}$ & Dimension & Indicator & Assessment criteria (employees) & Score & Criteria \\
\hline \multirow[t]{3}{*}{1} & \multirow{3}{*}{$\begin{array}{l}\text { employee } \\
\text { capabilities }\end{array}$} & a. Work hours provided & \multirow{3}{*}{$\begin{array}{l}\text { Using likert scale with answer core } \\
\text { are } 1,2,3,4,5 \text { with the employee sample } \\
\text { size of } 15 \text { people }\end{array}$} & 49 & Good enough \\
\hline & & b. Award given & & 33 & Not good \\
\hline & & c. Compensation provided & & 50 & Good enough \\
\hline
\end{tabular}




\begin{tabular}{|c|c|c|c|c|c|c|c|}
\hline & & d. The desire to get out of the workers & \multirow[t]{2}{*}{ No } & \multirow[t]{2}{*}{ Scale criteria } & \multirow{2}{*}{$\begin{array}{l}\text { Score } \\
\text { criteria }\end{array}$} & 68 & Very good \\
\hline \multirow[t]{3}{*}{2} & \multirow{3}{*}{$\begin{array}{l}\text { Information } \\
\text { system } \\
\text { capabilities }\end{array}$} & a. Availability of information & & & & 47 & Good enough \\
\hline & & \multirow[t]{2}{*}{ b. Socialization of information } & $\frac{1}{2}$ & $\begin{array}{l}14-25 \\
26-37 \\
\end{array}$ & $\begin{array}{l}\text { Bad } \\
\text { Not good } \\
\end{array}$ & \multirow[t]{2}{*}{50} & \multirow[t]{2}{*}{ Good } \\
\hline & & & 3 & $38-49$ & Good & & \\
\hline \multirow[t]{4}{*}{3} & \multirow{4}{*}{$\begin{array}{l}\text { Motivation } \\
\text { of } \\
\text { empowerme } \\
\text { nt and } \\
\text { alignment }\end{array}$} & a.Training for employees & & & enough & 41 & Good enough \\
\hline & & $\begin{array}{l}\text { b. Implementation of suggestions } \\
\text { provided by employees }\end{array}$ & $\begin{array}{l}4 \\
5 \\
\end{array}$ & $\begin{array}{l}50-61 \\
62-74 \\
\end{array}$ & $\begin{array}{l}\text { Good } \\
\text { Very good } \\
\end{array}$ & 52 & Good \\
\hline & & $\begin{array}{l}\text { c. Demonstrate the benefits of } \\
\text { suggestions }\end{array}$ & & & & & Good \\
\hline & & $\begin{array}{l}\text { d. Mutual goals of the organization } \\
\text { and employees }\end{array}$ & & & & & \\
\hline & Total & & & & & 49. & Good enough \\
\hline
\end{tabular}

Achievements of learning performance indicators and growth are included in the criteria good enough. This can be due to the cooperative is quite good in paying attention to its work, that is always provide adequate information about the business activities undertaken and disseminate the information to the employees.

From all previous discussions, if all the perspectives of cooperative performance are compared, then the internal business process perspective (good criterion) becomes a better perspective from another perspective (good enough criteria). Although the criteria for each perspective is good enough, to support the sustainability of its business activities, the cooperative is required to improve its performance to be even better.

In relation to efforts to achieve optimal financial performance, cooperatives have tried to use the assets optimally, but when viewed from the ratio of return on assets, the asset is not optimally used. Another effort by the cooperative is to continue to keep prices on the livestock feed unit, even though raw material prices rose by almost $80 \%$. This is done in order to give satisfaction to customers (members of the cooperative).

In relation to efforts to improve non-financial performance optimally, the efforts that have been made by the cooperative is to improve customer service infrastructure, timely service, product price adjustment, and receive input from customers. Cooperatives have also made efforts to improve the quality of facilities and equipment supporting employees for the work. In terms of learning and growth, although not yet maximal, cooperatives have conducted training for employees and members.
Cooperatives also have attempted to implement suggestions from employees.

\section{CONCLUSIONS AND SUGGESTION}

\subsection{Conclusion}

From the research results can be concluded as foilow.

1. From the side of liquidity and solvability shows that the cooperative able to pay its debts, the cooperative is financed by almost half of its debt. For rentability and activity ratio, indicating that cooperative is still not effective in obtaining SHU and still not effective in utilizing existing resources.

2. In general, performance from a non-financial perspective is quite good. However, compared to other perspectives, internal business perspective is better. Cooperatives have been working to provide new products, equipment and work facilities, price adjustments and handling customer complaints well.

\subsection{Suggestion}

Suggestions that can be delivered are, 1. Improving the effectiveness of cooperative services so that the products offered services will suit the needs and satisfaction of members. This can be done by conducting a survey of needs through a continuous questionnaire and providing suggestion and complaint contact services.

2. Looking for suppliers of products that can provide low prices for customers and minimize customer

complaints.

3. Adjusting employees' working hours, rewarding high performing employees and providing incentives to employees who can 
improve and encourage improvement of employee performance,

4. Facilitating the implementation of education and training for employees relating to business services and implementation of Balance Scorcard method, and for members related to the identity of the cooperative.

\section{REFERENCES}

[1] Guidara, R., \& Khoufi, W. (2014). Balanced scorecard and performance in a competitive environment. International Journal of Accounting and Economics Studies, 2(1), 40-45. http://doi.org/10.14419/ijaes.v2i1.2348

[2\}Don R. Hansen dan Maryanne M. Mowen .(1999). Akuntansi Manajemen Jilid 1 . E d4 . Erlangga : Jakarta

[3] Binden, W., Mziu, H., \& Suhaimi, A. (2014). Employing the Balanced Scorecard (BSC) to Measure Performance in Higher Education Malaysia. International Journal of Information and Communication Technology Research, 4(1), 38-44. Retrieved from http://www.esjournals.org

[4] Kopecka, N. (2015). The Balanced Scorecard Implementation, Integrated Approach and the Quality of Its Measurement. Procedia Economics and Finance, 25(15), 59-69. http://doi.org/10.1016/S22125671(15)00713-3

[5] Zin, N. M., Sulaiman, S., Ramli, A., \& Nawawi, A. (2013). Performance Measurement and Balanced Scorecard Implementation: Case Evidence of a Government-linked Company. Procedia Economics and Finance, 7(Icebr), 197204. http://doi.org/10.1016/S2212-
5671(13)00235-9

[6] Martín López, V. M., \& Ruiz Guerra, I. (2011). Strategic management for the internationalization and cooperative markets. Procedia - Social and Behavioral Sciences, 24, 769-780. http://doi.org/10.1016/j.sbspro.2011.09.1 11

[7] Guidara, R., \& Khoufi, W. (2014). Balanced scorecard and performance in a competitive environment. International Journal of Accounting and Economics Studies, 2(1), 40-45. http://doi.org/10.14419/ijaes.v2i1.2348

[8] Purwono, J., Sugyaningsih, S., \& Roseriza, A. (2013). Analisis Kinerja Koperasi Produksi Susu dengan Pendekatan Balanced Scorecard Neo-Bis, 7) (1), 1-16

[9] Sinaga, P. (2015). Balanced Scorecard sebagai Pengukurân Kinerja Koperasi dan UKM, Apa Mungkin? Infokop, 12(25), $55-61$

[10] Sedera, D., Gable, G., \& Rosemann, M. (2001). A Balanced Scorecard Approach to Enterprise Systems Performance Measurement.

[11] Ikhsan, S., \& Ikhsan, S. (2012). Penerapan Balance Scorecard Sebagai Tolak Ukur Kinerja Pada KPRI dii Jawa Tengah. Jurnal Dinamika Akuntansi, 1(2), 117-124. Retrieved from http://journal.unnes.ac.id/nju/index.php/j da/article/view/1918

[12] Karni, W., Pertanian, F., \& Andalas, U. (2011). Analisis Kinerja Koperasi Unit Desa ( Kud ) Setia Nagari Selayo Kecamatan Kubung Analisis Kinerja Koperasi Unit Desa ( KUD ) Setia Nagari Selayo Kecamatan Kubung. 